\title{
Self-employment and over-indebtedness in Poland: Modelling income and debt repayments distribution
}

\author{
Agnieszka Wałęga, Grzegorz Wałęga
}

\begin{abstract}
A B S T R A C T
Objective: The objective of the article is to assess financial situation and debt repayments in households of self-employed individuals and compare them to these of other types of households. The article aims to identify the determinants of over-indebtedness.

Research Design \& Methods: The study focuses on households of self-employed. The results are based on a nationwide CATI survey conducted among 1107 Polish indebted households. Theoretical models of the income distribution (log-logistic, Burr III) and the power-exponential model were used to achieve the research goals.

Findings: The economic status of indebted households differentiates income and debt repayments distributions. Self-employed households have a better financial situation and greater inequalities than households of the paid employees and individuals sustaining themselves from other sources of income. The debt repayments of entrepreneurs are higher than in households of paid employees but lower than in other groups of households. The determinants of over-indebtedness are essentially similar regardless of the work status, but the impact of income, number of loans, and debt type on over-indebtedness is greater for self-employed households.

Implications \& Recommendations: The results on the debt repayments distribution and determinants of overindebtedness may be helpful in creating regulations that preventing household bankruptcies and policies aimed at combating social exclusion.

Contribution \& Value Added: Introducing the issue of self-employment into the discussion on income and debt distribution and identifying the over-indebtedness among households of self-employed. To assess the debt repayments, we adopt theoretical income distributions and unique source of data on Polish households in debt.

\section{Article type: research article}

Keywords: $\quad$ self-employed; household; over-indebtedness; income distribution, debt repayments JEL codes: $\quad$ G51, D14, D31, C51

Received: 2 May $2021 \quad$ Revised: 26 August $2021 \quad$ Accepted: 29 August 2021
\end{abstract}

\section{Suggested citation:}

Wałęga, A., \& Wałęga, G. (2021). Self-employment and over-indebtedness in Poland: Modelling income and debt repayments distribution. Entrepreneurial Business and Economics Review, 9(4), 51-65. https://doi.org/10.15678/EBER.2021.090404

\section{INTRODUCTION}

The financial standing of households is one of the basic factors impacting satisfaction of needs and the living conditions that determine the needs. With access to loans, current consumption may be increased above the level of income generated at a given time. Hence, debts constitute an important source of financing for household consumption. In 2009-2019, the gross debt-to-income ratio of households in Poland increased by over nine percentage points to $57.67 \%$. As in other countries of Central and Eastern Europe, this value is about 1.5 to two times lower than the average for the European Union. Moreover, this difference is almost fourfold in relation to the most debt-burdened households in the Nordic countries (Eurostat, 2020). The growing level of household indebtedness affects the ability to meet the needs, for example, by purchasing durable goods and real estate. This trend, however, carries the risk of overindebtedness - the burden of debt repayments may have a negative influence on the economic situation of households (Betti et al., 2007; Fatoki, 2015; Mutsonziwa \& Fanta, 2019); their well-being (Bialowolski 
et al., 2021; Brown \& Gray, 2016; Coste et al., 2020; Tay et al., 2017) and, more broadly, on the stability of the banking system (Ciukaj \& Kil, 2020).

While the issues related to household income, or more precisely the distribution of income, have been addressed in numerous studies (Jędrzejczak, 2009; Jędrzejczak \& Pekasiewicz, 2020; Kośny, 2013; Trzcińska, 2020; Ulman, 2020), the indebtedness of Polish households at the microeconomic level remains under-researched (Anioła-Mikołajczak, 2017; Białowolski, 2019; Wałęga \& Wałęga, 2021). The present study focuses on households with income based on self-employment, which has not raised much interest so far. In our opinion, what deserves attention is the feature of households ran by entrepreneurs, which manifests itself in volatile income and propensity to use external sources of financing. We employ a unique dataset on Polish indebted households. Data obtained from over 1100 respondents in a nationwide CATI survey allowed for a detailed analysis of the financial situation of households sustained by self-employed persons. Moreover, to the best of our knowledge, the proposed adaptation of theoretical income distributions to the assessment of debt repayment distribution is a novel methodological approach.

The purpose of the article is threefold. Firstly, it aims to assess financial situation in households of self-employed individuals and compare it to that of other types of households with the use of theoretical models of income distribution. There, the subject of interest is also the level of income inequality in households of self-employed individuals. Secondly, our goal is to compare the amount of household debt repayments in Poland between the self-employed, the employees, and individuals with other sources of income. Income and debt burden determine the purchasing power of household. On the basis of the above considerations, the degree of over-indebtedness in various types of households was determined. The third and final goal of the article is to identify the determinants of over-indebtedness with the use of regression modelling.

The article is organised as follows: firstly, we will review the literature with regard to income, indebtedness, and over-indebtedness in order to formulate research hypotheses. In the next section, we will present the data source and research methodology in detail. Then, we will discuss the results of our empirical research. What follows will be the presentation of income and debt repayment distributions, along with an exploration of their similarities. We identify the determinants of overindebtedness using the power-exponential model. The last part of the study will be a summary in which we refer to the hypotheses. In this part, we will present the broader implications of our research and outline its further directions.

\section{LITERATURE REVIEW}

Income inequalities have been the subject of many analyses by economists and statisticians. In recent years, these issues have gained importance due to their role in economic development. With knowledge about income distribution in society, we can now measure the quality of life, poverty, and welfare both in time and space (Łukasiewicz et al., 2018; Jędrzejczak \& Pekasiewicz, 2020; Kot, 2020). Apart from individual factors such as gender, age, abilities, talent, and health, the income inequality is influenced by external factors, among which assignment of household members to a specific socio-economic group plays an important role (Landmesser, 2019). Such nature of inequality requires that income distributions at the microeconomic level be analysed and compared between different types of households.

A review of previous studies indicates that households of self-employed individuals in Poland achieve relatively higher incomes than those of paid employees or other socio-economic groups (Szczygieł \& Piecuch, 2016; Ulman \& Wałęga, 2013). A similar situation is observed, for example, in the Czech Republic (Bartošová \& Bína, 2009). The advantage of the self-employed can be explained by their distinctive entrepreneurial personality traits, which determine the profitability of business (Sarwoko \& Nurfarida, 2021).

Many individuals want to become self-employed due to the autonomy and flexibility it brings (Binder \& Blankenberg, 2021). A very common reason for undertaking business activities by individuals is profit, 
which not only enables the development of their firms but also guarantees funds for supporting themselves and their families. Profit is the entrepreneur's compensation for the risk of losing not only company assets but also private capital resources in the event of bankruptcy. Previous research results show that there is a significant positive relationship between self-employment and happiness, life satisfaction (Crum \& Chen, 2015; Johansson Sevä et al., 2016), and job satisfaction (Benz \& Frey, 2008; Blanchflower, 2004). These relations are especially obvious for younger groups of employed which prefer higher independence to plan and maintain the work-life balance instead of incomes stability (Tvaronavičiene et al., 2021). On the other hand, some studies indicate the opposite effect: self-employment is associated with predominantly negative well-being effects (Bencsik \& Chuluun, 2021).

The work status is important considering that different labour groups are likely to differ in job security, flexibility in labour supply, and access to credit. It is justified especially for the groups of selfemployed and paid employees. These groups may experience different types of income fluctuations and deal with them in distinct ways. This is relevant for the income inequality in these groups (Albarran et al., 2009). Research on employment status and income inequality shows that the proportion of selfemployed in the labour force increases income dispersion (Halvarsson et al., 2018). Schneck (2020) confirmed also that self-employment is a source of income inequality. This can be associated with the attitude towards risk indicated by Friedman (1953). However, the impact of self-employment on income is more complex. Entrepreneurship has an indirect impact through employment creation, which seems to reduce income inequality, especially in regard to surviving companies (Gawet, 2020).

One of the most important factors that determine the level of household debt is income. In general, higher income is accompanied by a higher level of indebtedness, which can be explained by the positive correlation between the income, consumption aspirations, and creditworthiness. The inevitable consequence of higher indebtedness is a higher repayment burden, which in turn, increases the risk of overindebtedness. However, with rising income households borrow less relative to their income and also use a smaller proportion of their income for repayments (Wildauer, 2016). There are also many studies (Anderloni \& Vandone, 2008; Bridges \& Disney, 2004) that point to low-income levels as the cause of over-indebtedness, as they require more expensive forms of debt (e.g. loans from pawnbrokers and non-bank financial institutions) and result in lower resilience to consequences of unexpected events. Therefore, the relationship between the amount of debt repayment and income may be ambiguous: the financial situation of a household may have different effects on the level of debt.

The risk of over-indebtedness is also related to employment status. Yilmazer and DeVaney (2005) proved that self-employment has significant effects on the probability of holding both secured and unsecured debt. The work status affects not only the possibility to generate income but also determines its stability over time. Stable employment allows access to a greater number of credit instruments and enables obtaining more favourable interest rates. However, the above circumstances may encourage excessive indebtedness in absolute terms (Anderloni \& Vandone, 2008). Therefore, the amount of income may not be as decisive for the risk of over-indebtedness as employment stability and the cash flow it generates. Kempson (2002) indicates that financial difficulties are strongly associated with low and unstable incomes. These links are obvious during the pandemic period, when financial risks and their negative outcomes became more perceptible (Cepel et al., 2021). Magri (2007) argues that the reason for greater debt among the self-employed, despite the higher uncertainty of income and risks involved in their business activity, may stem from lesser perceived importance of precautionary saving in this group. Apart from the economic situation of entrepreneurs, the debt-related problems are also affected by socio-demographic characteristics. For instance, some researchers propose evidence that state support of microfinance programs aimed at widening the access to credit positively affects self-employment of women (Haque et al., 2019). Other stress that the risk of debt service difficulties in households of the self-employed increases if the household's head is poorly educated or is a woman (Sánchez-Martínez et al., 2016).

The work status affects not only the debt burden but also the types of credit instruments used. Debt among the self-employed is driven by the needs of small businesses, not by consumer and household finances (Castronova \& Hagstrom, 2004). This was confirmed, among others, by Kim (2017) who working on data from South Korea, indicated that the increase of self-employed business debt is closely 
linked to intensifying competition in the self-employed sector and the rise in business costs. It is a determinant that does not occur among other types of households.

Therefore, diagnosis of the income distribution in the self-employed households is of great importance if we are to better understand the distribution of debt repayments and thus over-indebtedness. The above-mentioned previous empirical results suggested the following research hypotheses:

H1: Households of the self-employed have a better income situation than other socio-economic groups, but their income distribution is characterised by greater inequality.

H2: Households of the self-employed have a higher level of debt burden and a higher risk of being over-indebted than those of other socio-economic groups.

H3: The main determinants of debt burden among the self-employed are the level of income, the number of loans, and the number of persons in a household.

\section{RESEARCH METHODOLOGY}

The study was based on a unique dataset obtained from the nationwide CATI survey conducted among Polish households in the second quarter of 2018. The CEM Market and Public Opinion Research Institute, a professional market and opinion research agency, partnered in the data collection phase of the survey. All the respondents were at least 18 years old and had one or more loan commitments (secured or unsecured). Finally, 1107 individuals from all over Poland were interviewed. The use of random sampling and sample size enabled us to generalise the results on indebted households in Poland.

The unit of analysis was the indebted household, not the individual respondent. The reason was that many decisions, such as the work status of family members and debt, are made at the household level. A household was classified as self-employed when the respondent obtained income from selfemployment or his own business.

The subject of analyses were the monthly income and the debt repayments per a household member. To describe the distribution of income per capita and debt repayments per capita, we employed the log-normal distribution, the log-logistic distribution, and the Burr III distribution. The estimation of income distribution parameters was performed by adjusting the selected theoretical distribution model to the actual data. We were able to compare the properties of theoretical models for the analyzed income in separate groups using descriptive statistics.

Let us note that since research on income distribution has over a hundred years of history in economic theory, many theoretical solutions have already been proposed for this problem. Using a mathematical function to describe income distribution was first proposed by Pareto. In the literature, the following distributions often appear: the log-normal distribution popularised in the area of research on income by Aitchison and Brown; distributions of the Burr type, namely the Burr Type XII described by Singh and Maddala in 1976 and the Burr Type III described by Dagum in 1977; along with the log-logistic distribution (Fisk distribution). A classification of the majority of theoretical frameworks used to model empirical income distributions is available in the work of McDonald and Xu (1995). On the basis of family income data, the above-mentioned researchers conclude that the generalised Beta distribution of the second type best approximates empirical income distributions. However, the Dagum distribution (Burr III) turns out to be only slightly worse according to the statistical fitting measures. The Dagum distribution is recognised in the income research literature as one of the best income distribution models (tukasiewicz \& Orłowski, 2004). This is also confirmed by Bandourian, McDonald, and Turley (2002) who found that the Dagum distribution is the best among the three-parameter distributions and better than the twoparameter distributions studied. The frequency of its use and its usefulness have been confirmed in many works, as documented in the study by Kleiber and Kotz (2003). The distribution was used also in Poland, for instance by Jędrzejczak (2009), Jędrzejczak and Pekasiewicz (2020), Ulman (2015), Wałęga and Wałęga (2017). Let us emphasise that a better fitting of a given theoretical distribution to specific empirical data does not mean that this distribution would also be the best model for other datasets (for a different sample, in a different period, or for different variables). 
In this study, the best results in the statistical sense (the lowest value of the Akaike information criterion) were obtained by the use of the two-parameter log-logistic Fisk model and the Burr III distribution. The density function in the Dagum distribution can be recorded as follows (Kleiber \& Kotz, 2003):

$$
f(y)=\frac{c b \exp (-a) y^{-(b+1)}}{\left[1+\exp (-a) y^{-b}\right]^{c+1}}
$$

in which $a, b$, and $c$ are distribution parameters.

The ordinary moment of order $r$ in this distribution is expressed as follows:

$$
m_{r}=B\left(1-\frac{r}{b}, c+\frac{r}{b}\right) \exp \left(\frac{-a}{b}\right) r c
$$

in which $B$ is the Euler's beta function. Using the formula (2), the average value of income can be determined as the ordinary moment of order $r=1$, while the standard deviation is obtained using the formula:

$$
D(Y)^{2}=m_{2}-\left(m_{1}\right)^{2}
$$

The formula for the Gini coefficient is as follows:

$$
G=\frac{\Gamma(c) \Gamma\left(2 c+\frac{1}{b}\right)}{\Gamma(2 c) \Gamma\left(c+\frac{1}{b}\right)}-1
$$

in which $\Gamma$ is Euler's gamma function.

In the log-logistic distribution, the density function can be recorded as follows (Kleiber \& Kotz, 2003):

$$
f(y)=\frac{b \exp (-(a+b \ln y))}{y[1+\exp (-(a+b \ln y))]^{2}}
$$

in which $a$ and $b$ are distribution parameters.

The expected value in this distribution is obtained using the formula:

and the standard deviation:

$$
E(Y)=\frac{\pi}{b \sin \left(\frac{\pi}{b}\right)} \exp \left(-\frac{a}{b}\right)
$$

$$
D(Y)=\sqrt{(E(Y))^{2}\left[\frac{b}{\pi} \operatorname{tg}\left(\frac{\pi}{b}\right)-1\right]}
$$

The income distribution inequality can be assessed using the Gini coefficient, which is given by the formula:

$$
G=\frac{1}{b}
$$

The fundamental issue for the practical application of the theoretical functions as models of income distributions is the knowledge of distribution parameters. Among many estimation methods, the most frequently used is the maximum likelihood estimation (MLE), which provides consistent, asymptotically unbiased, asymptotically efficient, and asymptotically normal estimators of parameters. To assess the matching rate of the theoretical distribution and the empirical income distribution values of the Akaike information criterion were applied.

The Sen index (9) was used to determine the measure of well-being (Ulman, 2015):

$$
W_{S}=\mu(1-G)
$$

The difference between the analysed distributions was measured by the Bhattacharyya $\left(D_{B}\right)$ distance (Bhattacharyya, 1943). It is based on a comparison of the density function of two distributions according to the formula (UIman \& Ćwiek, 2019):

in which $\rho=\int \sqrt{f_{1}(y) f_{2}(y)} d y$ and $\rho \in[0,1]$.

$$
D_{B}\left(f_{1}, f_{2}\right)=-\ln (\rho)
$$

The Bhattacharyya distance ranges from 0 to $\infty$. The value of zero indicates a perfect match between distributions, whereas the higher the value of this distance, the greater the difference between compared distributions.

Income and debt repayments were compared using the debt service to income ratio (DSTI). This ratio is commonly used as an objective criterion for determining which households are recognised as 
over-indebted (D’Alessio \& lezzi, 2013; Ntsalaze \& Ikhide, 2016; Sánchez-Martínez et al., 2016). Concurrently, regression modelling was used to assess the determinants of over-indebtedness. The analyses included linear, exponential, and power-exponential models. The best results (the highest coefficient of determination $R^{2}$ ) were obtained through the use of the power-exponential model:

$$
y_{i}=\alpha_{0} \prod_{j=1}^{s} x_{i j}{ }^{\alpha_{j}} \cdot \exp \left(\alpha_{s+1} x_{i s+1}+\alpha_{s+2} x_{i s+2}+\ldots+\alpha_{k} x_{i k}+\varepsilon_{i}\right)
$$

where:

$y_{i}$ - debt service to income of the $i$-th household,

$x_{i j}$ - $j$-th independent variable for the $i$-th household,

$\alpha_{j}$ - parameter for the $j$-th independent variable,

$\varepsilon_{i}$ - value of the random component for the $i$-th household.

The variable selection method was the stepwise regression, and the parameters were estimated using the least squares method. Among the independent variables for the model, the characteristics of the respondents (gender, age, education level) and their households (income, subjective assessment of the financial situation, number of persons, place of residence, floor area of the flat or house), but also variables characterising the household debt were used (number of loans, type of debt: bank (ref.), non-bank, mixed).

\section{RESULTS AND DISCUSSION}

Table 1 presents those results of estimation of theoretical models of income distribution per capita and debt repayments per capita, which were most relevant in a statistical sense (the lowest level of the Akaike information criterion), namely the Fisk logistic distribution and the Dagum distribution. In each of the presented models, all parameter estimates turned out to be statistically significant. This enabled the presentation of the studied distributions in two ways: by calculating their descriptive characteristics (Table 2) and by drawing graphs of density function (Figure 1).

The comparison of the density function graphs presented in Figure 1 allows us to conclude that both the distribution of debt repayments as well as the distribution of income are right-skewed. In both cases, the function for households of the self-employed is shifted to the right which means that they have, on average, higher incomes and higher debt repayments. The functions are also more flattened which indicates a greater dispersion around the mean, and thus their greater differentiation.

The information presented in Table 2 corroborates the findings obtained from the graphs analysis. Characteristics of income distribution indicate a significant difference between average values for the per capita income in households of the self-employed and paid employees compared to individuals sustaining themselves from other sources of income, in favour of the former. However, the difference between the dominants is not a major one. This is probably caused by very high incomes in some households of the self-employed, significantly exceeding both the incomes of the paid employees and the average level of entrepreneurs' earnings. This shifts the average income value towards its higher end without changing - in comparison to the range - the dominant value. This suggests that the income within the group of households of the self-employed is more diverse compared to the group of households of the paid employees and others. This is confirmed both by the coefficient of income variation and the Gini coefficient, which are significantly higher for households of the self-employed than other types of households. This agrees with the previous research by Merz (2000). Compared to the paid employees, the self-employed show greater income volatility because they are over-represented at both the left and right tails of the total income distribution (Carter, 2011). These inequalities also result from the heterogeneity of the self-employed as a group (Parker, 1997). 
Table 1. Estimation results for the distributions of income per capita and debt repayments

\begin{tabular}{|c|c|c|c|c|c|c|c|}
\hline Parameter & Estimator & $\begin{array}{l}\text { Standard } \\
\text { error }\end{array}$ & $Z$ statistics & $p$-value & $\begin{array}{l}\text { Likelihood } \\
\quad \text { ratio }\end{array}$ & $\begin{array}{l}\text { Bayesian infor- } \\
\text { mation criterion }\end{array}$ & $\begin{array}{l}\text { Akaike } \\
\text { criterion }\end{array}$ \\
\hline \multicolumn{8}{|c|}{ income per capita } \\
\hline \multicolumn{8}{|c|}{ self-employed* } \\
\hline$a$ & -17.039 & 1.334 & -12.770 & $<0.0001$ & \multirow{2}{*}{-1289.96} & \multirow{2}{*}{2589.89} & \multirow{2}{*}{2583.91} \\
\hline$b$ & 2.247 & 0.173 & 12.973 & $<0.0001$ & & & \\
\hline \multicolumn{8}{|c|}{ employees* } \\
\hline$a$ & -20.036 & 0.698 & -28.705 & $<0.0001$ & \multirow{2}{*}{-5607.25} & \multirow{2}{*}{11227.51} & \multirow{2}{*}{11218.50} \\
\hline$b$ & 2.714 & 0.094 & 28.920 & $<0.0001$ & & & \\
\hline \multicolumn{8}{|c|}{ others $* *$} \\
\hline$a$ & -28.180 & 4.173 & -6.752 & $<0.0001$ & \multirow{3}{*}{-1574.59} & \multirow{3}{*}{3164.96} & \multirow{3}{*}{3155.17} \\
\hline$b$ & 3.735 & 0.508 & 7.347 & $<0.0001$ & & & \\
\hline$c$ & 0.492 & 0.130 & 3.778 & 0.0002 & & & \\
\hline \multicolumn{8}{|c|}{ debt repayments per capita } \\
\hline \multicolumn{8}{|c|}{ self-employed** } \\
\hline$a$ & -12.722 & 2.458 & -5.177 & $<0.0001$ & \multirow{3}{*}{-1165.84} & \multirow{3}{*}{2347.02} & \multirow{3}{*}{2337.68} \\
\hline$b$ & 2.079 & 0.343 & 6.061 & $<0.0001$ & & & \\
\hline$c$ & 0.509 & 0.149 & 3.426 & 0.0006 & & & \\
\hline \multicolumn{8}{|c|}{ employees** } \\
\hline$a$ & -10.833 & 1.019 & -10.627 & $<0.0001$ & \multirow{3}{*}{-4879.87} & \multirow{3}{*}{9779.46} & \multirow{3}{*}{9765.73} \\
\hline$b$ & 1.908 & 0.145 & 13.169 & $<0.0001$ & & & \\
\hline$c$ & 0.668 & 0.104 & 6.425 & $<0.0001$ & & & \\
\hline \multicolumn{8}{|c|}{ others* } \\
\hline$a$ & -8.334 & 0.563 & -14.812 & $<0.0001$ & \multirow{2}{*}{-1442.27} & \multirow{2}{*}{2895.26} & \multirow{2}{*}{2888.54} \\
\hline$b$ & 1.582 & 0.107 & 14.799 & $<0.0001$ & & & \\
\hline
\end{tabular}

* - Fisk log-logistic distribution; ** - Dagum (Burr III) distribution.

Source: own elaboration of CATI survey data.
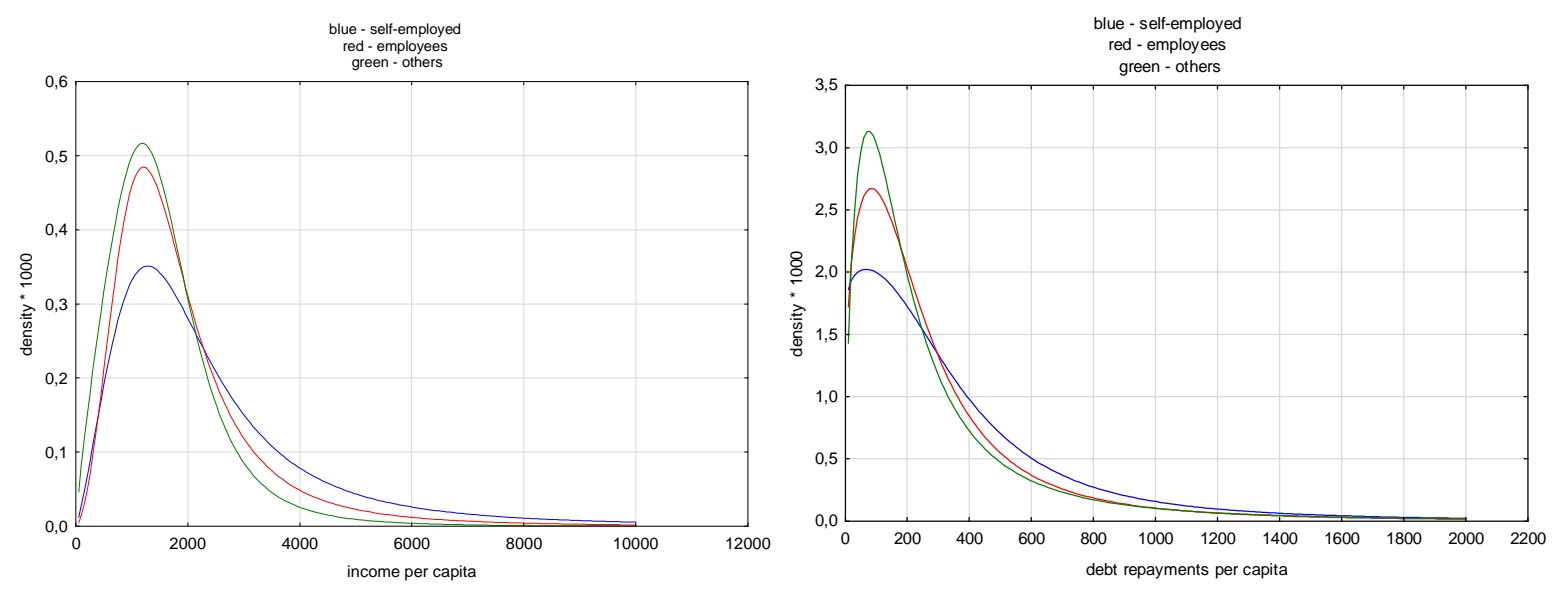

Figure 1. Income and debt repayments distribution in selected types of households Source: own elaboration of modelling results. 
A conglomerate of average incomes and their inequality included in the Sen index formula indicates that self-employment generates higher social welfare than income from hired work. Better financial situation of households of the self-employed in Poland are confirmed by Kośny (2013). The upper groups of income are dominated by households declaring paid employment and self-employment as their main source of income, while in the lower groups of income the share of such households is significantly lower. On the other hand, Szczygieł and Piecuch (2016) found that running a business by the head of a household contributes to higher average income than in other socioeconomic groups. The better financial position of self-employed individuals (compared to those relying on other sources of income) is also confirmed by studies conducted for the household as a whole by Ulman and Wałęga (2013) and separately for women and men by Ulman (2015).

Table 2. Characteristics of the distribution of income per capita and debt repayment per capita

\begin{tabular}{|l|c|c|c|}
\hline \multicolumn{1}{|c|}{ Measure } & Self-employed & Employees & Others \\
\hline \multicolumn{2}{|c|}{ income per capita } \\
\hline Mean (PLN) & 2786.18 & 2032.88 & 1592.03 \\
\hline Median (PLN) & 1963.26 & 1608.32 & 1398.43 \\
\hline Mode (PLN) & 1282.45 & 1209.53 & 1189.85 \\
\hline Third quartile (PLN) & 3201.10 & 2410.91 & 2011.66 \\
\hline Gini coefficient (\%) & 44.50 & 36.85 & 33.27 \\
\hline Coefficient of variation (\%) & 176.04 & 98.51 & 3.95 \\
\hline Sen index (PLN) & 1546.30 & 1283.80 & 1062.37 \\
\hline & debt repayments per capita & 421.74 \\
\hline Mean (PLN) & 449.19 & 370.16 & 194.27 \\
\hline Median (PLN) & 272.56 & 213.36 & 75.72 \\
\hline Mode (PLN) & 67.63 & 84.97 & 389.10 \\
\hline Third quartile (PLN) & 519.37 & 404.21 & 63.22 \\
\hline Gini coefficient (\%) & 55.01 & 56.09 & \\
\hline
\end{tabular}

Source: own elaboration of CATI survey data.

The distribution of debt repayment reveals higher inequalities than in the distribution of income. The values of the Gini coefficient exceed those calculated for income, with the largest inequalities in debt repayments occurring in households sustained from other sources of income. Repayments in households of the self-employed are, on average, higher than in other households, but the inequalities in this group are among the lowest.

Therefore, it becomes reasonable to determine whether the income and debt repayment distributions differ between the studied groups of households. For this purpose, the differences between these distributions in the surveyed household groups were assessed using the Bhattacharyya distance (Table 3). Generally, the distance between the distributions is not large, but the greatest differences can be noticed between the income distribution within households of the self-employed and those sustained from other sources of income. On the other hand, the greatest distance separates the distribution of debt repayments in households of the self-employed and the paid employees.

The more favourable income situation means that households of entrepreneurs generally have higher nominal monthly debt repayments, which nevertheless does not translate into a much greater debt burden in relation to income. This agrees with the findings by Wildaeur (2016), which show that with rising income, households use a smaller proportion of their income for debt repayments. The average debt service to income ratio (DSTI) in these households is about $20 \%$, while it amounts to about $18 \%$ for households of the paid employees and to $25 \%$ for other groups of households. 
Table 3. Bhattacharyya distance (DB) between the distributions of income per capita and debt repayment per capita for selected groups of households

\begin{tabular}{|l|c|c|c|c|c|c|}
\hline \multirow{2}{*}{ Specification } & \multicolumn{3}{|c|}{ Income per capita } & \multicolumn{3}{c|}{ Debt repayments per capita } \\
\cline { 2 - 7 } & self-employed & employees & others & self-employed & employees & others \\
\hline Self-employed & 0 & 0.0200 & 0.0470 & 0 & 0.0214 & 0.0128 \\
\hline Employees & 0.0200 & 0 & 0.0257 & 0.0214 & 0 & 0.0187 \\
\hline Others & 0.0470 & 0.0257 & 0 & 0.0128 & 0.0187 & 0 \\
\hline
\end{tabular}

Source: own elaboration of CATI survey data.

A greater debt burden increases the risk of over-indebtedness. Considering the DSTI ratio, regardless of the adopted threshold, the financial situation of households sustained from other sources of income is the worst (Figure 2). However, we should note that the higher the DSTI level is adopted as the threshold of over-indebtedness, the smaller the difference in share of over-indebted households between the group of the self-employed and others. The percentage of over-indebted households in the self-employed group is higher than in the paid employees, albeit by no more than 1.8 percentage points. Assuming that over-indebted households have DSTI > 30\% (D'Alessio \& lezzi, 2013, 2016; Michelangeli \& Pietrunti, 2014; Tiongson et al., 2009), the self-employed group included $16.3 \%$ of such households, the paid employee group $-14.6 \%$, while other work status groups $-24.5 \%$. These results are consistent with the findings from previous research using the DSTI as a measure of over-indebtedness. Self-employed households are generally more likely to be over-indebted compared to those in which the head is a paid employee (D’Alessio \& lezzi, 2016; Du Caju et al., 2016). Moreover, Yilmazer and DeVaney (2005) confirm that self-employment has significant effects on the debt ratios but only for other types of credit (other than mortgage, credit cards, and instalments). Furthermore, other research indicates that self-employment may be associated with a more serious debt repayment problem: mortgage arrears (Duygan-Bump \& Grant, 2009) or insolvency.

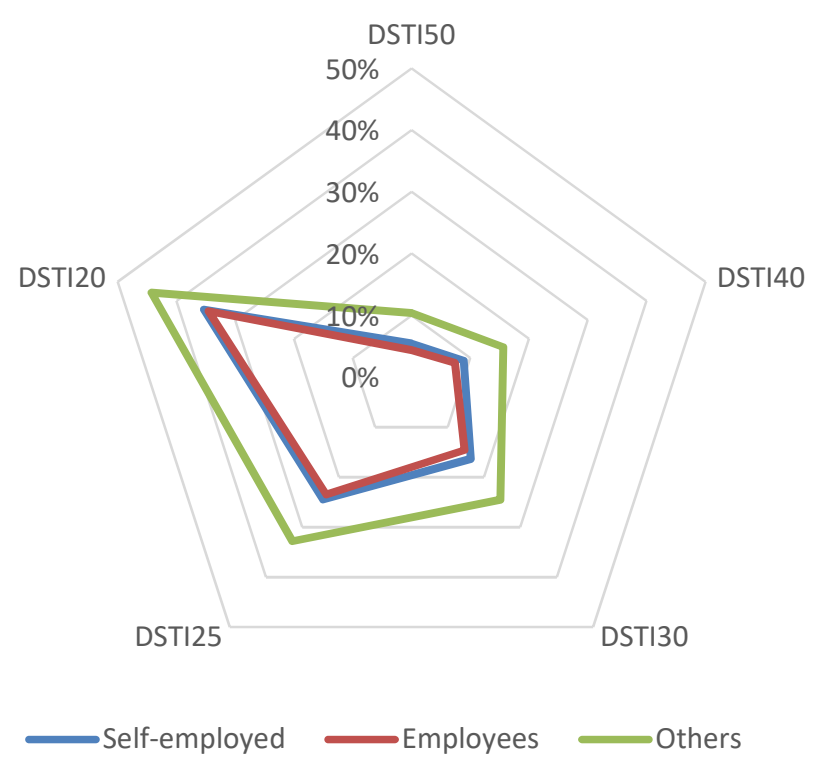

Figure 2. Over-indebtedness according to the DSTI ratio for selected groups of households Source: own elaboration of CATI survey data.

Figure 3 presents the empirical DSTI distribution ratios for the analysed household groups. Within each group, the distribution of this ratio can be defined as multimodal. For households sustained from other sources of income, but also among the self-employed, we notice outliers as the ratio exceeds $100 \%$. 


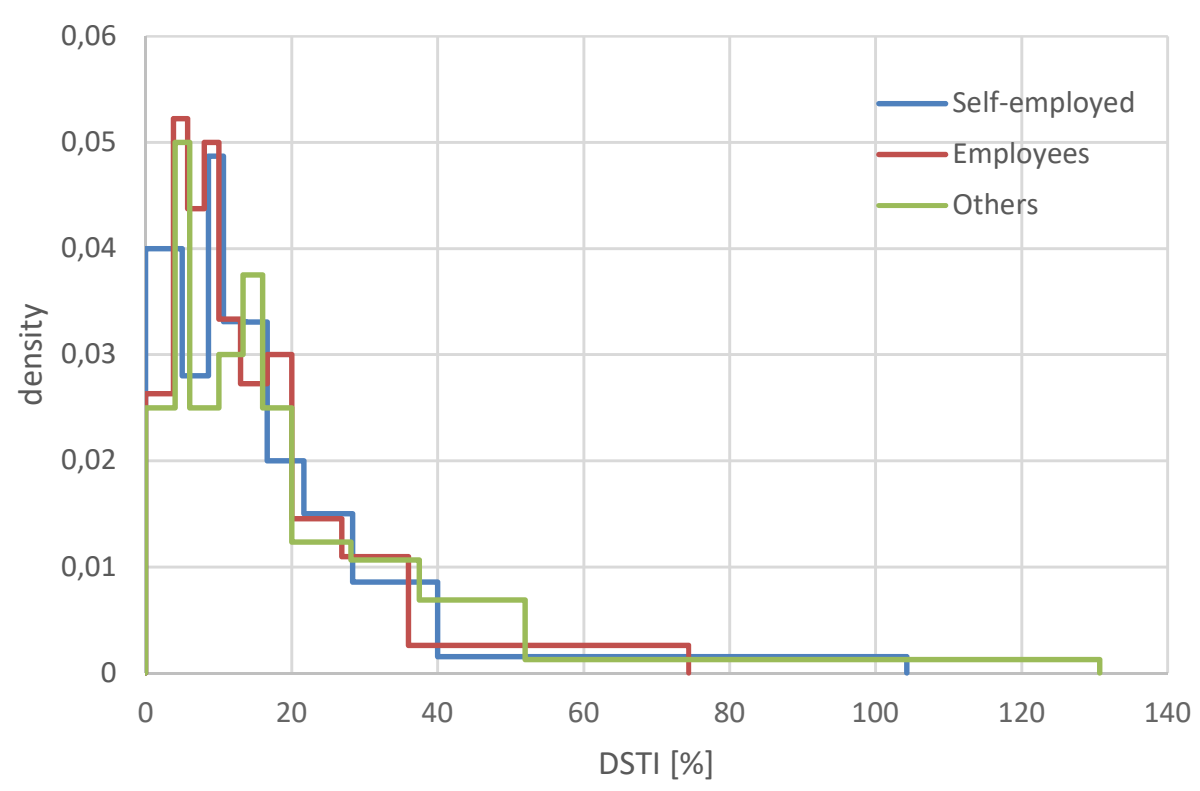

Figure 3. Empirical distribution of the DSTI ratio

Source: own elaboration of CATI survey data.

Due to the fact that an excessively high share of debt repayments in income may lead to overindebtedness, it seems reasonable to identify the factors determining this relationship and to examine whether they differ depending on the type of household. For this purpose, we estimated the parameters of the power-exponential model for the DSTI (dependent variable). Among the independent variables, we considered the characteristics of the respondents, their households, and their debt, for which we used backward stepwise regression. Following this approach, only the statistically significant variables that determined the DSTI ratio remained in the model.

Table 3. Power-exponential model: estimation results

\begin{tabular}{|c|c|c|c|c|c|c|c|c|c|}
\hline \multirow[b]{2}{*}{ Specification } & \multicolumn{3}{|c|}{ Self-employed } & \multicolumn{3}{|c|}{ Employees } & \multicolumn{3}{|c|}{ Others } \\
\hline & Parameter & $\begin{array}{c}\text { Standard } \\
\text { error }\end{array}$ & p-value & Parameter & $\begin{array}{c}\text { Standard } \\
\text { error }\end{array}$ & $p$-value & Parameter & $\begin{array}{c}\text { Standard } \\
\text { error }\end{array}$ & p-value \\
\hline Constant & 7.462 & 0.816 & 0.0000 & 6.778 & 0.424 & 0.0000 & 6.242 & 0.747 & 0.0000 \\
\hline Education & - & - & - & 0.147 & 0.041 & 0.0003 & - & - & - \\
\hline No. of persons & -0.245 & 0.065 & 0.0002 & -0.285 & 0.029 & 0.0000 & -0.191 & 0.051 & 0.0002 \\
\hline $\operatorname{In}$ (income) & -0.620 & 0.094 & 0.0000 & -0.543 & 0.054 & 0.0000 & -0.475 & 0.096 & 0.0000 \\
\hline Flat area & - & - & - & 0.001 & 0.001 & 0.0249 & - & - & - \\
\hline No. of loans & 0.595 & 0.101 & 0.0000 & 0.343 & 0.042 & 0.0000 & 0.432 & 0.080 & 0.0000 \\
\hline Non-banking & -1.294 & 0.166 & 0.0000 & -0.960 & 0.063 & 0.0000 & -0.872 & 0.127 & 0.0000 \\
\hline Mixed & -0.464 & 0.235 & 0.0501 & -0.183 & 0.092 & 0.0480 & - & - & - \\
\hline \multicolumn{10}{|c|}{ Model fitting } \\
\hline$R^{2}$ & \multicolumn{3}{|c|}{0.4615} & \multicolumn{3}{|c|}{0.4073} & \multicolumn{3}{|c|}{0.3633} \\
\hline F statistics & \multicolumn{3}{|c|}{$F(5.141)=24.17 p<0.001$} & \multicolumn{3}{|c|}{$F(7.657)=66.18 p<0.001$} & \multicolumn{3}{|c|}{$F(4.187)=28.25 p<0.001$} \\
\hline Standard error & \multicolumn{3}{|c|}{0.8263} & \multicolumn{3}{|c|}{0.6953} & \multicolumn{3}{|c|}{0.7859} \\
\hline$N$ & \multicolumn{3}{|c|}{147} & \multicolumn{3}{|c|}{665} & \multicolumn{3}{|c|}{192} \\
\hline
\end{tabular}

Source: own elaboration of CATI survey data.

The results in Table 3 show that the increase in the DSTI ratio, and thus the risk of over-indebtedness, is influenced by the number of loans (in any analysed group of households) and, in the case of paid employees, also by the level of education and the floor area. Generally, the factors determining 
the level of DSTI ratio do not differ substantially between the analysed groups of households. However, we should note that the impact of income, number of loans, and type of debt (non-bank and mixed) in households of the self-employed is stronger than in other groups.

\section{CONCLUSIONS}

The analysis of income distribution and income inequality has a long history. The novelty of the present study lies in introducing the perspective of self-employment into the discussion on income and debt distribution and the problem of over-indebtedness.

The research carried out on a sample of Polish indebted households shows that the economic status differentiates distributions of income and debt repayments. Therefore, it is justified to study these household groups separately. The self-employed households have a better financial situation than households of paid employees and individuals who support themselves from other sources of income. On the other hand, the Gini coefficient confirms the occurrence of greater inequalities in distribution of income for households of entrepreneurs compared to other analysed groups. These results agree with expectations and confirm greater income inequality for this group of households. Thus, the conducted analyses allow us to positively verify hypothesis $\mathrm{H} 1$. The households of entrepreneurs exhibit the income debt burden higher than those of paid employees but lower than households of individuals who support themselves from other sources of income. This may suggest that greater income fluctuation leads to over-indebtedness. In this context, we may assume that hypothesis $\mathrm{H} 2$ is partially confirmed. On the other hand, the identification of the variables that determine the extent to which income is encumbered with repayments did not show any fundamental differences: the determinants are essentially similar regardless of the work status. However, the impact of income, credit, and type of debt on the over-indebtedness is greater for households of the self-employed.

The limitation of this study is that the analysis concerned only a single year. A longitudinal study focused on the situation of the self-employed would certainly prove valuable. Moreover, the group of self-employed households is very heterogeneous, which results in high income inequality. Therefore, future analyses should distinguish more homogeneous types of self-employed households (e.g. freelancers, entrepreneurs, etc.). Moreover, future research should scrutinise the characteristics of the debt held by self-employed households because - as Castronova and Hagstrom (2004) and Yilmazer and DeVaney (2005) indicate - the type of their debt is different from other households. However, this would require gathering more detailed data and a different research methodology based on in-depth interviews with entrepreneurs. Such an approach would shed light on self-employment and perhaps challenge the findings made in this study. Given that the situation of self-employed workers depends on the local context and the conditions in which they operate (Erkut, 2016; Onwe et al., 2020), we believe future scholarship should prepare an international comparative study on income and debt among households of the self-employed. It would also be valuable to compare the financial situation of indebted and non-indebted households of self-employed.

The use of debt increases the range of consumer choices and is a necessary function in the modern economy. At the same time, as long as borrowing is available, some people will get into difficulties with debt. However, as is the case with poverty, appropriate policies can reduce the risk. Research results on debt distribution and its determinants may help to create regulations that prevent household bankruptcies and policies aimed at combating social exclusion. Identifying the characteristics of over-indebted households could also allow for designing better solutions that would increase stability of the financial system and provide debt counselling for groups prone to over-indebtedness.

\section{REFERENCES}

Albarran, P., Carrasco, R., \& Martinez-Granado, M. (2009). Inequality for Wage Earners and Self-Employed: Evidence from Panel Data. Oxford Bulletin of Economics and Statistics, 71(4), 491-518. https://doi.org/10.1111/j.1468-0084.2009.00549.x 
Anderloni, L., \& Vandone, D. (2008). Households over-indebtedness in the economic literature (Universit'a Degli Studi Di Milano Working Paper No. 46).

Anioła-Mikołajczak, P. (2017). The impact of age on Polish households financial behavior - indebtedness and over-indebtedness. Optimum. Economic Studies, 1(85), 106-116.

Bandourian, R., McDonald, J. B., \& Turley, R. S. (2002). A Comparison of Parametric Models of Income Distribution Across Countries and Over Time. Luxembourg Income Study Working Paper, 305. https://doi.org/10.2139/ssrn.324900

Bartošová, J., \& Bína, V. (2009). Modelling of Income Distribution of Czech Households in The Years 1996-2005. Acta Oeconomica Pragensia, 17(4), 3-18. https://doi.org/10.18267/j.aop.275

Bencsik, P., \& Chuluun, T. (2021). Comparative well-being of the self-employed and paid employees in the USA. Small Business Economics, 56(1), 355-384. https://doi.org/10.1007/s11187-019-00221-1

Benz, M., \& Frey, B. S. (2008). The value of doing what you like: Evidence from the self-employed in 23 countries. Journal of Economic Behavior \& Organization, 68(3-4), 445-455. https://doi.org/10.1016/j.jebo.2006.10.014

Betti, G., Dourmashkin, N., Rossi, M., \& Ping Yin, Y. (2007). Consumer over-indebtedness in the EU: Measurement and characteristics. Journal of Economic Studies, 34(2), 136-156. https://doi.org/10.1108/01443580710745371

Bhattacharyya, A. (1943). On a Measure of Divergence between Two Multinomial Populations. Bulletin of the Calcutta Mathematical Society, 35, 99-110.

Białowolski, P. (2019). Patterns and evolution of consumer debt: Evidence from latent transition models. Quality \& Quantity, 53(1), 389-415. https://doi.org/10.1007/s11135-018-0759-9

Bialowolski, P., Weziak-Bialowolska, D., \& McNeely, E. (2021). The Role of Financial Fragility and Financial Control for Well-Being. Social Indicators Research, 155(3), 1137-1157. https://doi.org/10.1007/s11205-021-02627-5

Binder, M., \& Blankenberg, A.-K. (2021). Self-employment and Subjective Well-Being (SSRN Scholarly Paper ID 3768347). Social Science Research Network. https://doi.org/10.2139/ssrn.3768347

Blanchflower, D. (2004). Self-Employment: More may not be better (No. w10286; p. w10286). National Bureau of Economic Research. https://doi.org/10.3386/w10286

Bridges, S., \& Disney, R. (2004). Use of credit and arrears on debt among low-income families in the United Kingdom. Fiscal Studies, 25(1), 1-25. https://doi.org/10.1111/j.1475-5890.2004.tb00094.x

Brown, S., \& Gray, D. (2016). Household finances and well-being in Australia: An empirical analysis of comparison effects. Journal of Economic Psychology, 53, 17-36. https://doi.org/10.1016/j.joep.2015.12.006

Carter, S. (2011). The Rewards of Entrepreneurship: Exploring the Incomes, Wealth, and Economic Well-Being of Entrepreneurial Households. Entrepreneurship Theory and Practice, 35(1), 39-55. https://doi.org/10.1111/j.1540-6520.2010.00422.x

Castronova, E., \& Hagstrom, P. (2004). The Demand for Credit Cards: Evidence from the Survey of Consumer Finances. Economic Inquiry, 42(2), 304-318. https://doi.org/10.1093/ei/cbh062

Cepel, M., Gavurova, B., Dvorsky, J., \& Belas, J. (2020). The impact of the COVID-19 crisis on the perception of business risk in the SME segment. Journal of International Studies, 13(3), 248-263. http://doi.org/10.14254/2071-8330.2020/13-3/16

Ciukaj, R., \& Kil, K. (2020). Determinants of the non-performing loan ratio in the European Union banking sectors with a high level of impaired loans. Economics and Business Review, 20(1), 22-45. https://doi.org/10.18559/ebr.2020.1.2

Coste, T., Henchoz, C., \& Wernli, B. (2020). Debt and Subjective Well-Being: Does the Type of Debt Matter? Swiss Journal of Sociology, 46(3), 445-465. https://doi.org/10.2478/sjs-2020-0022

Crum, M., \& Chen, Y. (2015). Self-employment and subjective well-being: A multi-country analysis. International Journal of Entrepreneurship, 19, 15.

Ćwiek, M. T., \& Ulman, P. (2019). Income and Poverty in Households in Selected European Countries. Acta Universitatis Lodziensis. Folia Oeconomica, 6(345), 7-25. https://doi.org/10.18778/0208-6018.345.01

D’Alessio, G., \& lezzi, S. (2013). Household over-indebtedness: Definition and measurement with Italian data. Bank of Italy Occasional Paper, 149. https://doi.org/10.2139/ssrn.2243578

D'Alessio, G., \& lezzi, S. (2016). Over-indebtedness in Italy: How widespread and persistent is it? Bank of Italy Occasional Paper, 349. https://doi.org/10.2139/ssrn.2772485 
Du Caju, P., Rycx, F., \& Tojerow, I. (2016). Unemployment risk and over-indebtedness: A micro-econometric perspective (ECB Working Paper No. 1908). Frankfurt am Main: European Central Bank.

Duygan-Bump, B., \& Grant, C. (2009). Household debt repayment behaviour: What role do institutions play? Economic Policy, 24(57), 108-140. https://doi.org/10.1111/j.1468-0327.2009.00215.x

Erkut, B. (2016). Entrepreneurship and Economic Freedom: Do Objective and Subjective Data Reflect the Same Tendencies? Entrepreneurial Business and Economics Review, 4(3), 11-26. https://doi.org/10.15678/EBER.2016.040302

Eurostat. (2020). Gross debt-to-income ratio of households. https://ec.europa.eu/eurostat/databrowser/view/tec00104/default/table?lang=en

Fatoki, O. (2015). The Causes and Consequences of Household Over-Indebtedness in South Africa. Journal of Social Sciences, 43(2), 97-103. https://doi.org/10.1080/09718923.2015.11893427

Friedman, M. (1953). Choice, Chance, and the Personal Distribution of Income. Journal of Political Economy, 61(4), 277-290. https://doi.org/10.1086/257390

Gaweł, A. (2020). Does Entrepreneurship Affect Income Inequality within Countries? Direct and Indirect Effects in European Countries. Entrepreneurial Business and Economics Review, 8(2), 93-110. https://doi.org/10.15678/EBER.2020.080205

Haque, T., Siwar, C., Bhuiyan, A.B., \& Joarder, M.H.R. (2019). Contributions of Amanah Ikhtiar Malaysia (AIM) microfinance to Economic Empowerment (EE) of women borrowers in Malaysia. Economics and Sociology, 12(4), 241-256. https://doi.org/10.14254/2071-789X.2019/12-4/15

Halvarsson, D., Korpi, M., \& Wennberg, K. (2018). Entrepreneurship and income inequality. Journal of Economic Behavior \& Organization, 145, 275-293. https://doi.org/10.1016/j.jebo.2017.11.003

Jędrzejczak, A. (2009). Comparing Income Distributions - Methods and their Application to Wage Distributions in Poland. Acta Universitatis Lodziensis. Folia Oeconomica, 225, 271-282.

Jędrzejczak, A., \& Pekasiewicz, D. (2020). Teoretyczne rozkłady dochodow gospodarstw domowych $i$ ich estymacja. Łódź: Wydawnictwo Uniwersytetu Łódzkiego.

Johansson Sevä, I., Vinberg, S., Nordenmark, M., \& Strandh, M. (2016). Subjective well-being among the selfemployed in Europe: Macroeconomy, gender and immigrant status. Small Business Economics, 46(2), 239253. https://doi.org/10.1007/s11187-015-9682-9

Kempson, E. (2002). Over-indebtedness in Britain [Report]. Bristol: Personal Finance Research Centre, University of Bristol.

Kim, D. (2017). The Duality of Self-Employed Business Debt and its Increase after the Asian Financial Crisis. Journal of the Korean Welfare State and Social Policy, 1(2), 24-50.

Kleiber, C., \& Kotz, S. (2003). Statistical size distributions in economics and actuarial sciences. New Jersey: John Wiley \& Sons.

Kośny, M. (2013). Economic activity, saving, credit and income polarisation in Poland. Post-Communist Economies, 25(4), 512-528. https://doi.org/10.1080/14631377.2013.844931

Kot, S.M. (2020). Estimating the parameter of inequality aversion on the basis of a parametric distribution of incomes. Equilibrium. Quarterly Journal of Economics and Economic Policy, 15(3), 391-417. https://doi.org/10.24136/eq.2020.018

Landmesser, J. (2019). Differences in income distributions for men and women in the European Union countries. Equilibrium. Quarterly Journal of Economics and Economic Policy, 14(1), 81-98. https://doi.org/10.24136/eq.2019.004.

Łukasiewicz, P., Karpio, K., \& Orłowski, A. (2018). Two-component structure of household income distributions in Poland. Equilibrium. Quarterly Journal of Economics and Economic Policy, 13(4), 603-622. https://doi.org/10.24136/eq.2018.029

Łukasiewicz, P., \& Orłowski, A. (2004). Probabilistic models of income distributions. Physica A: Statistical Mechanics and Its Applications, 344(1-2), 146-151. https://doi.org/10.1016/j.physa.2004.06.106

Magri, S. (2007). Italian households' debt: The participation to the debt market and the size of the loan. Empirical Economics, 33(3), 401-426. https://doi.org/10.1007/s00181-006-0107-0

McDonald, J. B., \& Xu, Y. J. (1995). A generalization of the beta distribution with applications. Journal of Econometrics, 66(1), 133-152. https://doi.org/10.1016/0304-4076(94)01612-4 
Merz, J. (2000). The Distribution of Income of Self-employed, Entrepreneurs and Professions as Revealed from Micro Income Tax Statistics in Germany. In R. Hauser \& I. Becker (Eds.), The Personal Distribution of Income in an International Perspective (pp. 99-128). Springer Berlin Heidelberg. https://doi.org/10.1007/978-3-642-57232-6_6

Michelangeli, V., \& Pietrunti, M. (2014). A microsimulation model to evaluate Italian households' financial vulnerability. International Journal of Microsimulation, 7(3), 53-79. https://doi.org/10.34196/ijm.00107

Mutsonziwa, K., \& Fanta, A. (2019). Over-indebtedness and its welfare effect on households: Evidence from the Southern African countries. African Journal of Economic and Management Studies, 10(2), 185-197. https://doi.org/10.1108/AJEMS-04-2018-0105

Ntsalaze, L., \& Ikhide, S. (2016). Household over-indebtedness: Understanding its extent and characteristics of those affected. Journal of Social Sciences, 48(1-2), 79-93. https://doi.org/10.1080/09718923.2016.11893573

Onwe, C. C., Ogbo, A., \& Ameh, A. A. (2020). Entrepreneurial orientation and small firm performance: The moderating role of environmental hostility. Entrepreneurial Business and Economics Review, 8(4), 67-84. https://doi.org/10.15678/EBER.2020.080404

Parker, S. C. (1997). The Distribution of Self-employment Income in the United Kingdom, 1976-1991. The Economic Journal, 107(441), 455-466. https://doi.org/10.1111/j.0013-0133.1997.170.x

Sánchez-Martínez, M. T., Sanchez-Campillo, J., \& Moreno-Herrero, D. (2016). Mortgage debt and household vulnerability: Evidence from Spain before and during the global financial crisis. International Journal of Housing Markets and Analysis, 9(3), 400-420. https://doi.org/10.1108/IJHMA-07-2015-0038

Sarwoko, E., \& Nurfarida, I. N. (2021). Entrepreneurial marketing: Between entrepreneurial personality traits and business performance. Entrepreneurial Business and Economics Review, 9(2), 105-118. https://doi.org/10.15678/EBER.2021.090207

Schneck, S. (2020). Self-employment as a source of income inequality. Eurasian Business Review, 10(1), 45-64. https://doi.org/10.1007/s40821-019-00143-8

Szczygieł, E., \& Piecuch, T. (2016). Rozkłady dochodów przedsiębiorców i ich użyteczność na tle innych grup społeczno-ekonomicznych. Nierówności społeczne a wzrost gospodarczy, 48(4), 116-128. https://doi.org/10.15584/nsawg.2016.4.9

Tay, L., Batz, C., Parrigon, S., \& Kuykendall, L. (2017). Debt and subjective well-being: The other side of the incomehappiness coin. Journal of Happiness Studies, 18(3), 903-937. https://doi.org/10.1007/s10902-016-9758-5

Tiongson, E. R., Sugawara, N., Sulla, V., Taylor, A., Gueorguieva, A. I., Levin, V., \& Subbarao, K. (2009). The crisis hits home: Stress-testing households in Europe and Central Asia [Raport]. Washington: The World Bank. https://doi.org/10.1596/978-0-8213-8222-6

Trzcińska, K. (2020). Analysis of Household Income in Poland Based on the Zenga Distribution and Selected Income Inequality Measure. Folia Oeconomica Stetinensia, 20(1), 421-436.

Tvaronavičienè, M., Mazur, N., Mishchuk, H., \& Bilan, Y. (2021). Quality of life of the youth: assessment methodology development and empirical study in human capital management. Economic ResearchEkonomska Istraživanja, 1-18. https://doi.org/10.1080/1331677X.2021.1956361

Ulman, P. (2015). Income of household members in Poland. Folia Oeconomica Cracoviensia, LVI, 23-34.

Ulman, P. (2020). Changes in household income distribution after the introduction of social policy programmes in Poland. Nierówności Społeczne a Wzrost Gospodarczy, 63(3), 7-23. https://doi.org/10.15584/nsawg.2020.3.1

Ulman, P., \& Wałęga, A. (2013). Hired labour versus self-employment. Comparison of income distribution. In M. Papież \& S. Śmiech (Eds.), Proceedings of the 7th Professor Aleksander Zeliaś International Conference on Modelling and Forecasting of Socio-Economic Phenomena: Conference proceedings (pp. 190-197). Cracow: Foundation of the Cracow University of Economics.

Wałęga, A., Wałęga, G. (2017). Modelling the distribution of loan repayments of households in Poland. In: M. Papież \& S. Śmiech (Eds.), The 11th Professor Aleksander Zeliaś International Conference on Modelling and Forecasting of Socio-Economic Phenomena: Conference proceedings (pp. 437-446). Cracow: Foundation of the Cracow University of Economics.

Wałęga, G., \& Wałęga, A. (2021). Over-indebted households in Poland: Classification tree analysis. Social Indicators Research, 153(2), 561-584. https://doi.org/10.1007/s11205-020-02505-6

Wildauer, R. (2016). Determinants of US household debt: New evidence from the SCF (PKSG Working Paper No. 1608; Economics Discussion Papers). Faculty of Arts and Social Sciences, Kingston University.

Yilmazer, T., \& DeVaney, S. A. (2005). Household debt over the life cycle. Financial Services Review, 14, 285-304. 


\section{Authors}

The contribution share of authors is equal and amounted to $50 \%$ for each of them.

\section{Agnieszka Wałęga}

PhD, Assistant Professor at Cracow University of Economics (Poland), Department of Statistics at the College of Economics, Finance, and Law. Her research interests include social and labour statistics, statistical analysis of household budgets, poverty, well-being and household indebtedness (especially over-indebtedness).

Correspondence to: dr Agnieszka Wałęga, Cracow University of Economics, Department of Statistics, ul. Rakowicka 27, 31-510 Kraków, Poland, e-mail: agnieskza.walega@uek.krakow.pl

ORCID (1) http://orcid.org/0000-0002-6386-0433

\section{Grzegorz Wałęga}

$\mathrm{PhD}$, Assistant Professor at Cracow University of Economics (Poland), Department of Microeconomics at the College of Economics, Finance, and Law. He conducts research on household debt, over-indebtedness and financial well-being. His research interests focus on household economics, household finance and microeconomics.

Correspondence to: dr Grzegorz Wałęga, Cracow University of Economics, Department of Microeconomics, ul. Rakowicka 27, 31-510 Kraków, Poland, e-mail: grzegorz.walega@uek.krakow.pl

ORCID (1) http://orcid.org/0000-0002-4355-5204

\section{Acknowledgements and Financial Disclosure}

This study was supported by funds from the National Science Centre (NCN, Poland) through grant no. 2015/19/D/HS4/02569

\section{Conflict of Interest}

The authors declare that the research was conducted in the absence of any commercial or financial relationships that could be construed as a potential conflict of interest.

\section{Copyright and License}

This article is published under the terms of the Creative Commons

Attribution - NoDerivs (CC BY-ND 4.0) License

http://creativecommons.org/licenses/by-nd/4.0/ 
